\title{
Analysis of Effect of Human Capital, Infrastructure Investment and Infrastructure Consumption of Economic Growth in Indonesia
}

\author{
Rusy Dina ${ }^{1}$, Sri Ulfa Sentosa ${ }^{2}$, Efrizal Sofyan ${ }^{3}$ \\ ${ }^{1}$ Universitas Negeri Padang, Padang, Indonesia, $\bowtie$ rusydina.unp@gmail.com \\ 2 Universitas Negeri Padang, Padang, Indonesia, $\bowtie$ sriulfasentosa66@gmail.com \\ ${ }^{3}$ Universitas Negeri Padang, Padang, Indonesia , $₫$ efrizal_syofyan@yahoo.com
}

\begin{abstract}
This study aims to analyze the effect of Human Capital, Infrastructure Investment and Infrastructure Consumption on Economic Growth in Indonesia. The data used is the time series. Data analysis in this study uses OLS (Ordinary Least Square) equation test. The results showed that Human Capital had a positive effect on Economic Growth, and Infrastructure Consumption had a positive influence on Economic Growth in, whereas Infrastructure Investment did not have a significant influence on Indonesia's economic growth.
\end{abstract}

Keywords: Economic growth, human capital, infrastructure investment, infrastructure consumption.

\section{Introduction}

Economic growth in Indonesia on average is in the range of $5 \%$ (percent). It was proven from 2000 - 2010, the highest figure exceeding 5\% (percent) occurred in 2007 at $6.35 \%$ (percent) (BPS, 2018). Indonesia is a developing country that is making improvements in its economic system. In the process of increasing economic growth, there needs to be a process of sustainable economic development. Economic development starts from creating quality resources that are potential and competitive. The role of government is needed to improve the quality of human resources or capital and the availability of infrastructure facilities so that it can contribute to economic growth.

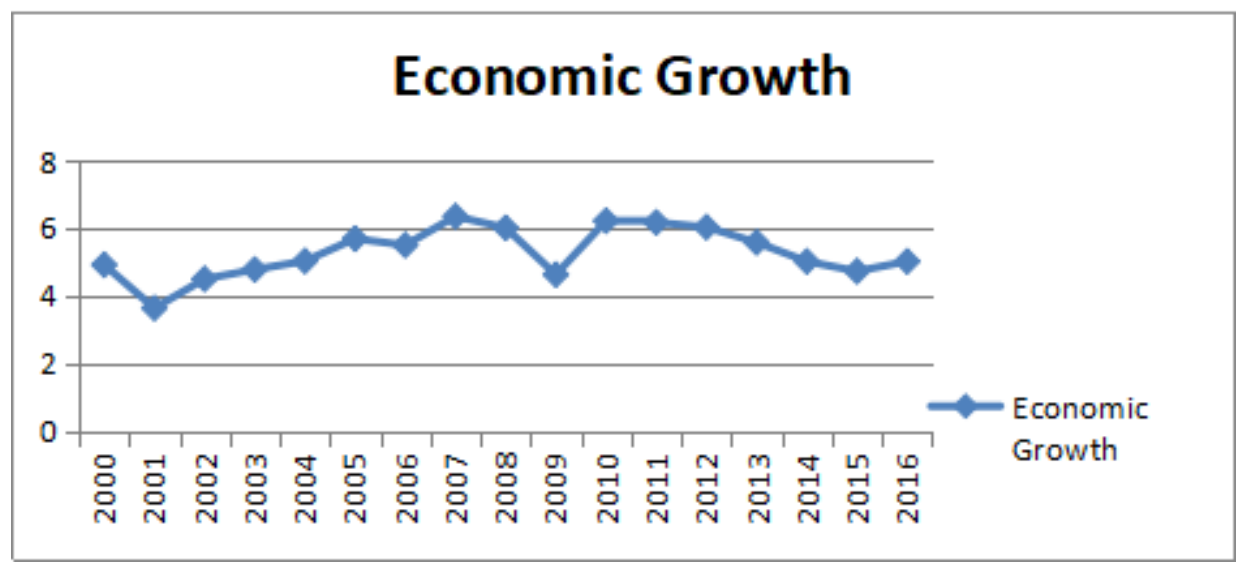

Source: Central Bureau of Statistics of Indonesian, 2018

Figure 1 Indonesia's economic growth 2000 - 2016

Economic development in the form of non-physical can be done by maximizing the use of human capital. According to (Jungsoo, 2006), 2006 that economic growth is influenced by the level of public education and productivity. Quality education and good health are a measure of human 
capital (Todaro, 2006). The research findings by (Ogundari, Kolawole., 2017) state that human capital such as education and health influences African economic growth, an increase in education and health increases economic growth. Government spending on education influences economic growth to be more increasing (Ono \& Uchida, 2018). Human capital has a large influence on economic growth (Mobolaji, 2010). Indonesia with a large population, which ranks fourth in the world for the largest number of populations, is a strong capital to increase economic growth and progress. The human capital that can be seen based on education and health in Indonesia tends to increase every year and can be seen in Figure 1 below:

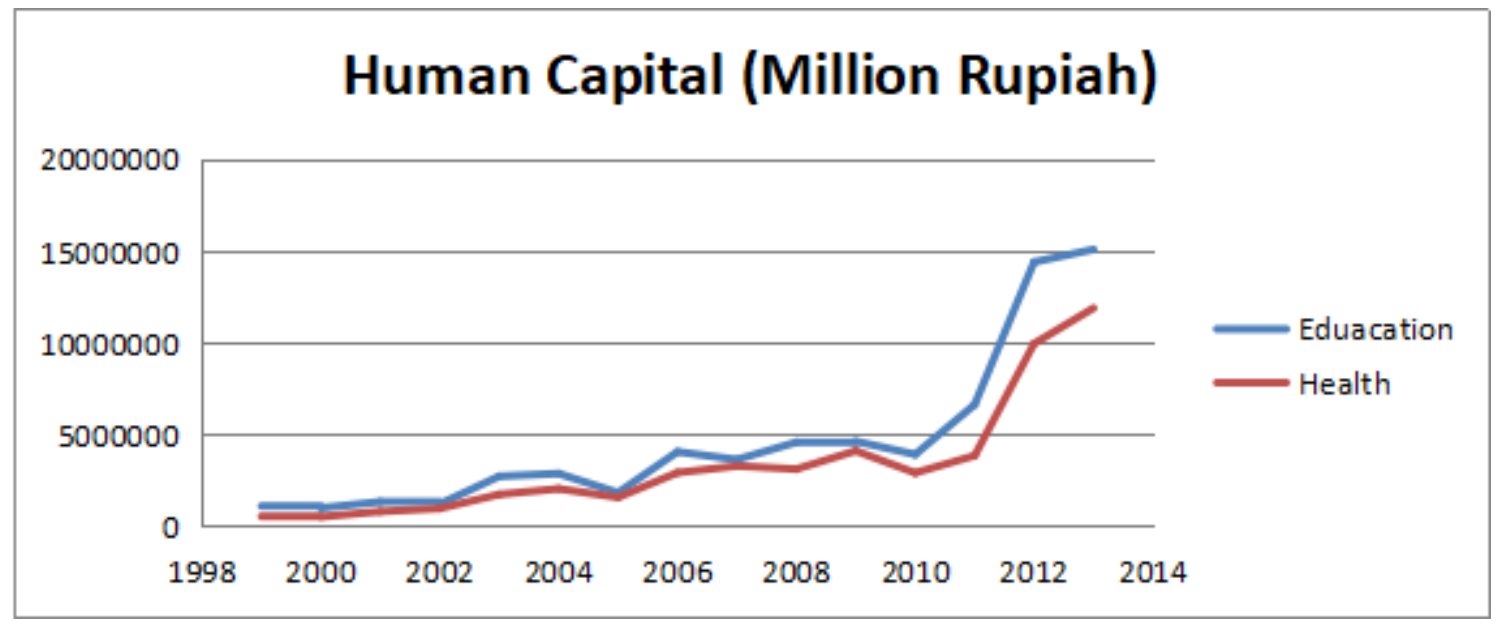

Source : Ministry of Finance RI, 2018

Figure 2 Human Capital in Indonesia

In addition to human capital on education and health, other factors that can influence economic growth to be increased our investment, in this case, infrastructure investment. Harrod-Domar argues that investment is a key role in economic growth because investment can generate income and enlarge economic production capacity, in this case, increasing capital stock (Jhingan, 2014). Research findings by (Jiang, He, Zhang, Qin, \& Shao, 2017) that infrastructure investment, especially on transportation, has a positive influence on economic growth at the national and provincial levels in China. Investment in the infrastructure sector positively affects both direct and indirect economic growth in Spain (Herranz-Loncán, 2007).

Based on Figure 3, it can be seen that the rate of investment in infrastructure in Indonesia fluctuates and tends to increase over the period 2000 - 2016. Consumption can be a factor that affects economic growth. Infrastructure consumption in energy such as oil and renewable energy influences economic growth in Turkey (Kose Erkan, Serhat Burmaoglu, 2016). In the long run, infrastructure consumption, especially energy consumption, positively influences long-term economic growth (Vidyarthi, 2015). 


\section{Infrastructure Investment (Million Rupiah)}

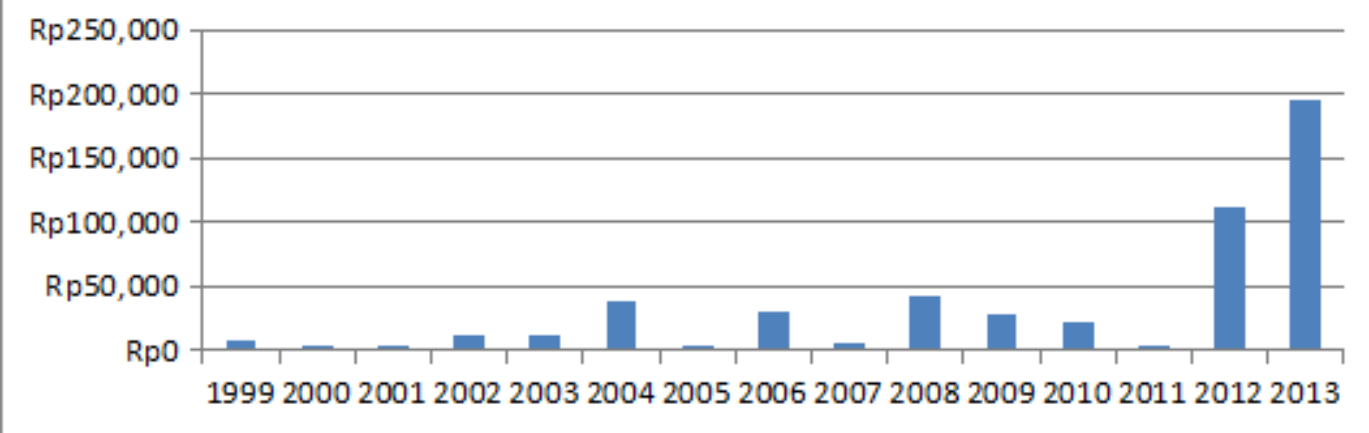

Source: (Worldbank, 2018)

Figure 3 Infrastructure Investment in Indonesia

According to (Chen \& Fang, 2017) found that industrial electricity consumption has a positive impact on economic growth in China. Infrastructure consumption in energy is an important factor in economic growth (Tang, Choor Foon, Bee Wah Tan, 2016). There is a long-term relationship between the consumption of transportation energy infrastructure and economic growth in MENA, where consumption increases economic growth in the Middle East (Saidi, Shahbaz, \& Akhtar, 2018). The following figure 4 shows the development of per capita infrastructure consumption in Indonesia during the period of 2000 - 2016. It can be seen that the per capita infrastructure consumption in Indonesia during 2000 - 2016 tends to increase. This is thought to affect the increase in economic growth

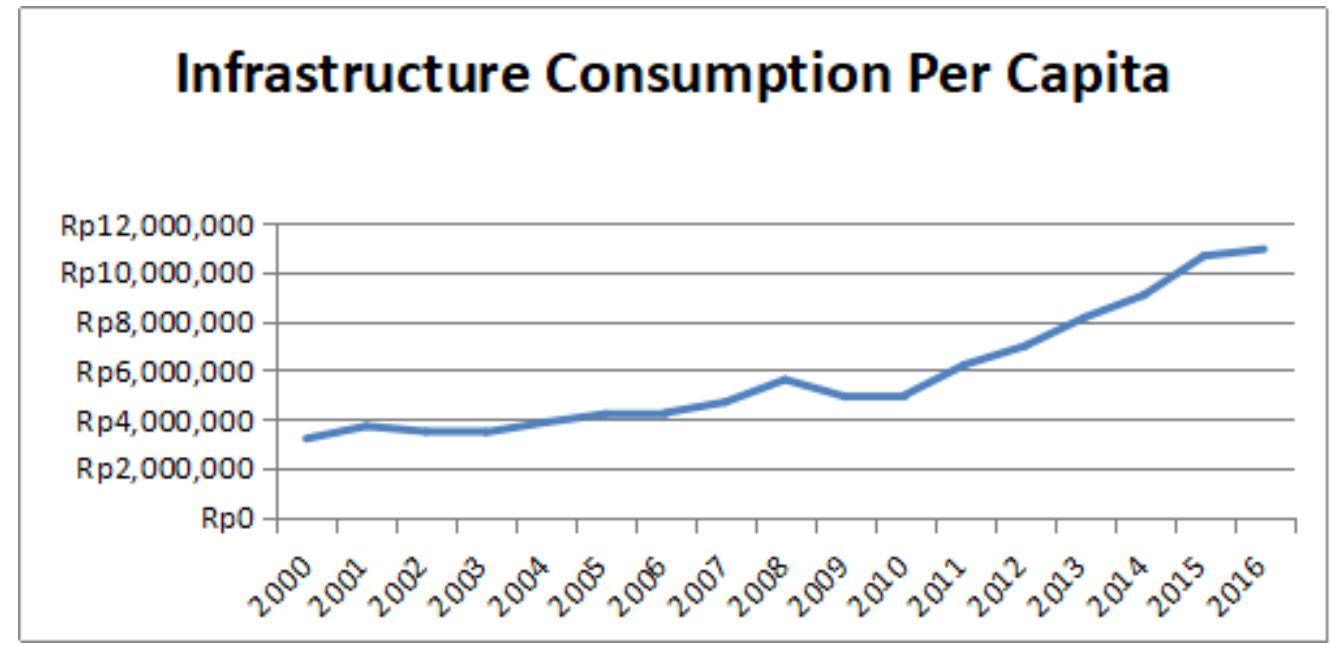

Source: (Worldbank, 2018)

Figure 4 The development of infrastructure per capita consumption in $2000-2016$

Based on the phenomenon described above the author is interested in conducting research with the title Analysis of the Effect of Human Capital, Infrastructure Investment, Infrastructure Consumption on Economic Growth in Indonesia 


\section{Methods}

This study uses time series data, namely data consisting of several time periods, and sourced from documentary data, namely data that has been published by certain agencies (Gujarati, 2015) such as the Indonesian Central Bureau of Statistics, Indonesian Ministry of Finance Publications, and the World Bank. The model used is Ordinary Least Square (OLS). Mathematically the OLS regression equation model in this study is as follows:

$$
\mathrm{Y}_{\mathrm{it}}=\alpha_{0}+\alpha_{1} \mathrm{X}_{1}+\alpha_{2} \mathrm{X}_{2}+\alpha_{3} \mathrm{X}_{3}+\mathrm{U}_{\mathrm{t}}
$$

To equalize the unit of unit count in the equation above, the OLS model is changed in the form of a logarithmic equation, then equation 1 becomes as follows:

$$
\log Y_{i t}=\alpha_{0}+\alpha_{1} \log X_{1}+\alpha_{2} \log X_{2}+\alpha_{3} \log X_{3}+U_{t}(2)
$$

Where $Y$ is Indonesia's Economic Growth as measured by Gross Domestic Product at a constant 2010 price in millions of Rupiah per year, $\alpha_{0}$ is a constant, $\alpha_{1,2,3,4}$ is a regression coefficient, $\mathrm{X}_{1}$ is is Human Capital as measured by government investment in the education and health sector in millions of Rupiah per year, $\mathrm{X}_{2}$ is Infrastructure investment is measured by the number of infrastructure investments in the energy, transport, water, and sanitation Indonesian Rupiah expressed in millions per year with a time lag of 2 years, $X_{3}$ is is Infrastructure Consumption measured by the amount of per capita consumption in infrastructure (especially electricity) in Rupiah per year, $\mathrm{U}_{\mathrm{t}}$ is residual (error term).

\section{Results and Discussion}

Table 1 shows the results of stationarity tests using a unit root test with different levels, where the results of the root test of this unit show no data that is not stationary at the second level.

Table 1Unit Root Test Results

\begin{tabular}{lcc}
\hline \multicolumn{1}{c}{ Variable } & Degree & Probability (ADF Test 1\%, 5\%, \\
& & $\mathbf{1 0 \% )}$ \\
\hline Economic Growth $(\mathrm{Y})$ & & 0,0000 \\
Human Capital $\left(\mathrm{X}_{1}\right)$ & $2^{\text {nd }}$ difference & 0,0062 \\
Infrastructure Investment $\left(\mathrm{X}_{2}\right)$ & & 0,0340 \\
Infrastructure Consumption $\left(\mathrm{X}_{3}\right)$ & 0,0050 \\
\hline Cointegration Test : & & \\
Residual & Level & 0,0005 \\
\hline
\end{tabular}

Source: Processed by Author, 2018

Based on the results of the stationary test, it can be concluded that there are no problems in the time series data in this study, it can be continued with the OLS regression test and the residual value when the co-integration test is stationary at the level. Table 2 shows the OLS regression test results as follows: 
Table 2 OLS regression test results

Result of regression test (OLS)

\begin{tabular}{lcc}
\hline \multicolumn{1}{c}{ Variable } & Coefficient & Probability \\
\hline Constants $(C)$ & 17,95 & 0,0000 \\
Human Capital $\left(\log X_{1}\right)$ & 0,154 & 0,0000 \\
Infrastructure Investment $\left(\log X_{2}\right)$ & 0,017 & 0,1209 \\
Infrastructure Consumption $\left(\log X_{3}\right)$ & 0,155 & 0,0000
\end{tabular}

Note : degree of error $\alpha=0,05$

$\mathrm{F}($ Prob $)=254,20$

R-Squared $=0,9658$

Source: Processed by Author, 2018

Based on Table 2, the following OLS equations can be made:

$Y_{t}=17,95+0,154 \log X_{1 t}+0,016 \log X_{2 t}+0,155 \log X_{3 t}$

\section{Discussion}

Based on the regression results above, the model can be simultaneously accepted because the Prob (F-Statistics) is smaller than the 0.05 degree of error. So that the value of R-Squared can be interpreted, where the R-Squared value of the OLS equation is 0.965 or 96.5 percent. This shows that the contribution of variable Human Capital, Infrastructure Investment and Infrastructure Consumption is $96.5 \%$ (percent), while the remaining 3.5 percent is influenced by other variables not included in the model.

\section{Effect of Human Capital on Economic Growth}

Human capital in this study is that government spending in education and health has a positive and significant effect on economic growth seen from a probability value of $0.0000<\alpha 0.05$. This means that the more investment in human capital, the more economic growth in Indonesia will increase. Human capital is needed to prepare humans who are ready to use in the world of work. The better the quality of human capital will increase the productivity of the community, the higher income will be in achieving social and material welfare. This condition will affect the increasing economic growth in the long run.

These results are relevant to the results of research conducted by (Mobolaji, 2010) which states that there is a strong influence on human capital in education on economic growth. Likewise with research (Ono \& Uchida, 2018) which found that government spending on education increases human capital so that wage levels increase and ultimately will increase production output which has an impact on increasing economic growth. In accordance with the research conducted by (Liang, 2010) that human capital in health has a positive and significant effect on economic growth. In line with research by (Ogundari, Kolawole., 2017) that human capital has a positive influence on economic growth, and a greater influence is the influence of the health sector for economic growth. Likewise with research by (Gong, Li, \& Wang, 2012) who found that human capital in health affected economic growth as a result of increasing health facilities and increased health levels.

\section{Effect of Infrastructure investment on Economic Growth}

Infrastructure investment has a positive and not significant effect on economic growth seen from a probability value of $0.017>\alpha 0.05$. This means that the positive influence between infrastructure 
investment on economic growth in Indonesia indicates that economic growth in Indonesia is affected by changes in the level of infrastructure investment. If infrastructure investment increases, economic growth will also increase, but the effect is not significant. Thus, it means that infrastructure investment in the long term does not contribute significantly to economic growth in Indonesia.

The results of the analysis obtained are not relevant to the research by (Song \& Van Geenhuizen, 2014) which states that infrastructure investment has a positive influence on economic growth even though the positive influence does not have a direct impact on economic growth. Likewise with research (Jiang et al., 2017) who found that infrastructure investment has a positive influence on economic growth. This research is not relevant also by research (Herranz-Loncán, 2007) which states that the growth of infrastructure investment has a positive influence on economic growth.

\section{Effect of Infrastructure Consumption on Economic Growth}

Infrastructure Consumption has a positive and significant effect on Economic Growth seen from a probability value of $0,000<\alpha 0,05$. The estimated coefficient is 0.155 which means that if infrastructure consumption increases by one percent then economic growth also increases by 0.155 percent assuming other variables remain (caterer-paribus). This means that a significant and positive influence between infrastructure consumption on economic growth indicates that if infrastructure consumption increases, economic growth will also increase. Increased infrastructure consumption in Indonesia is characterized by the large consumption of infrastructure facilities, especially electricity available around the community. People consume the most electricity in urban areas and use electricity during rush hour for office or company activities. This is what supports community activities in production and consumption activities. So that community contributions in infrastructure consumption activities contribute to growth in the infrastructure sector and ultimately can increase economic growth in Indonesia.

This result is relevant to the research conducted by (Kose \& Burmaoglu, 2016) which states that infrastructure consumption, especially on renewable energy can increase economic growth in Turkey. In accordance with a research by (Tang, 2016) which states that infrastructure consumption, especially energy positively influences economic growth. In addition, this research is relevant to research by (Chen \& Fang, 2017) which states that the consumption of infrastructure, especially industrial electricity, contributes greatly to economic growth.

\section{Conclusions}

Human capital has a positive and significant influence on economic growth in Indonesia. Based on these results it can be concluded that the higher the coefficient of influence of human capital means the greater the influence on economic growth

Infrastructure investment has a positive and not significant effect on economic growth. The increasing level of infrastructure investment, in the long run, does not have a significant effect on economic growth. This is due to the unequal investment invested in each region in Indonesia, resulting in income inequality and uneven welfare of the people in Indonesia.

Infrastructure consumption has a positive and significant influence on economic growth. The higher the level of consumption there is an increase in the level of economic growth in Indonesia. This means that infrastructure consumption has a significant effect on economic growth in Indonesia, which is characterized by an influence coefficient of 15.49 percent. 


\section{References}

BPS. (2018). BPS Indonesia. Badan Pusat Statistik 1986 - 2016. Retrieved from http://www.bps.go.id

Chen, Y., \& Fang, Z. (2017). Industrial electricity consumption, human capital investment and economic growth in Chinese cities. Economic Modelling, (March). https://doi.org/10.1016/j.econmod.2017.09.021

Gong, L., Li, H., \& Wang, D. (2012). China Economic Review Health investment, physical capital accumulation, and economic growth is, 23(220), 1104-1119. https://doi.org/10.1016/j.chieco.2012.07.002

Gujarati, D. N. (2015). Dasar-dasar Ekonometri (5th ed.). Jakarta: Salemba Empat.

Herranz-Loncán, A. (2007). Infrastructure investment and Spanish economic growth, 1850-1935. Explorations in Economic History, 44(3), 452-468. https://doi.org/10.1016/j.eeh.2006.06.002

Jhingan, M. L. (2014). Ekonomi Pembangunan dan Perencanaan. Jakarta: Raja Grafindo Persada.

Jiang, X., He, X., Zhang, L., Qin, H., \& Shao, F. (2017). Multimodal Transportation Infrastructure Investment and Region Economic Development: A Structural Equation Modelling Empirical in China from 1986 to 2011. Elsevier - Transport Policy, 54(November 2014), 43-52.

Jungsoo, P. (2006). Dispersion of human capital and economic growth. Journal of Macroeconomics, 28(3), 520-539. https://doi.org/10.1016/j.jmacro.2004.09.004

Kose Erkan, Serhat Burmaoglu, M. K. (2016). Grey Relational Anlysis between Energy Consumption and Economic Growth. Grey Systems: Theory and Aplication, 3(No. 3 2003). Retrieved from http://dx.doi.org//10.1108/GS-06-2013-0010

Liang, H. L. H. (2010). Health, Education, and Economic Growth in East Asia. Journal of Chinese Economic and Foreign Trade Studies, 3(2), 110-131. https://doi.org/10.1108/10569211211204492

Mobolaji, H. I. (2010). Banking development, human capital and economic growth in Sub-Saharan $\begin{array}{lllll}\text { Africa (SSA). Journal of Economic Studies, 37(5), 557-577. } & \end{array}$ https://doi.org/10.1108/01443581011075479

Ogundari, Kolawole., T. A. (2017). Human Capital Contribution to Economic Growth in SubSaharan Africa: Does Health Status Matter More than Education? Economic Analysis and Policy. https://doi.org/10.1016/jeap.2018.02.001

Ono, T., \& Uchida, Y. (2018). Human capital, public debt, and economic growth: A political economy analysis. Journal of Macroeconomics, 57, 1-14. https://doi.org/10.1016/j.jmacro.2018.03.003

Saidi, S., Shahbaz, M., \& Akhtar, P. (2018). The long-run relationships between transport energy consumption, transport infrastructure, and economic growth in MENA countries. Transportation Research Part A: Policy and Practice, 111(October 2017), 78-95. https://doi.org/10.1016/j.tra.2018.03.013

Song, L., \& van Geenhuizen, M. (2014). Port infrastructure investment and regional economic growth in China: Panel evidence in port regions and provinces. Transport Policy, 36, 173-183. https://doi.org/10.1016/j.tranpol.2014.08.003

Tang, Choor Foon, Bee Wah Tan, I. O. (2016). Energy Consumption and Economic Growth in Vietnam. Renewable and Sustainable Energy Reviews, (54), 1506-1514. Retrieved from http://dx.doi.org/10.1016/j.rser.2015.10.083

Todaro, M. \& S. C. S. (2006). Ekonomi Pembangunan. Jakarta: Erlangga.

Vidyarthi, H. (2015). Energy consumption and growth in South Asia: evidence from a panel error correction model. International Journal of Energy Sector Management, 9(3 pp-). Retrieved from http://dx.doi.org/10.1108/IJESM-10-2013-0002 
Worldbank. (2018). Public Private Participation in Infrastructure Project Database. Retrieved from https://data.worldbank.org 